\title{
Iron-Catalyzed Reductive Amination of Aldehydes in Isopropyl Alcohol/Water Media as Hydrogen Sources
}

This is the peer reviewed version of the following article:

Original:

Petricci, E., Santillo, N., Castagnolo, D., Cini, E., Taddei, M. (2018). Iron-Catalyzed Reductive Amination of Aldehydes in Isopropyl Alcohol/Water Media as Hydrogen Sources. ADVANCED SYNTHESIS \& CATALYSIS, 360(13), 2560-2565 [10.1002/adsc.201701619].

Availability:

This version is availablehttp://hdl.handle.net/11365/1057740

since 2018-08-21T18:27:28Z

\section{Published:}

DOI:10.1002/adsc.201701619

Terms of use:

Open Access

The terms and conditions for the reuse of this version of the manuscript are specified in the publishing policy. Works made available under a Creative Commons license can be used according to the terms and conditions of said license.

For all terms of use and more information see the publisher's website.

\section{Publisher copyright}

Wiley (Post-print)

This is the peer reviewed version of the following article which has been published in final form at (see DOI above).

This article may be used for non-commercial purposes in accordance with Wiley Terms and Conditions for Use of Self-Archived Versions. 


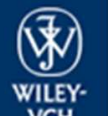

Advanced Synthesis \& Catalysis

\section{An Iron Catalyzed Reductive Amination of Aldehydes in Isopropyl Alcohol I/Water media as Hydrogen Sources}

\begin{tabular}{|r|l|}
\hline Journal: & Advanced Synthesis \& Catalysis \\
\hline Manuscript ID & adsc.201701619.R1 \\
\hline Wiley - Manuscript type: & Update \\
\hline Complete List of Authors: & $\begin{array}{l}\text { Petricci, Elena; University of Siena, Dipartimento di Biotecnologie, Chimica } \\
\text { e Farmacia } \\
\text { Santillo, Niccolò; University of Siena, Dipartimento di Biotecnologie, } \\
\text { Chimica e Farmacia } \\
\text { Castagnolo, Daniele; King's College London, Institute of Pharmaceutical } \\
\text { Science } \\
\text { Cini, Elena; Università di Siena, Dipartimento Farmaco Chimico Tecnologico } \\
\text { Taddei, Maurizio; University of Siena, Dipartimento di Biotecnologie, } \\
\text { Chimica e Farmacia }\end{array}$ \\
\hline Keywords: & \begin{tabular}{l} 
Amines, Iron, Microwave heating, Reduction, Hydrides \\
\hline Note: The following files were submitted by the author for peer review, but cannot be converted to \\
\hline You must view these files (e.g. movies) online.
\end{tabular} \\
\hline \begin{tabular}{l} 
Graphic files.zip \\
\hline
\end{tabular}
\end{tabular}


DOI: 10.1002/adsc.201((will be filled in by the editorial staff))

\title{
An Iron Catalyzed Reductive Amination of Aldehydes in Isopropyl Alcohol/Water media as Hydrogen Sources
}

\author{
Elena Petricci, ${ }^{\mathrm{a}, *}$ Niccolò Santillo, ${ }^{\mathrm{a}}$ Daniele Castagnolo, ${ }^{\mathrm{b}}$ Elena Cini, ${ }^{\mathrm{a}}$ and Maurizio \\ Taddei ${ }^{\mathrm{a}, *}$
}

a Dipartimento di Biotecnologie, Chimica e Farmacia, Università degli Studi di Siena, Via A. Moro 2, 53100 Siena Italy E-mail: elena.petricci@unisi.it; maurizio.taddei@unisi.it

b School of Cancer and Pharmaceutical Sciences, King's College London, 150 Stamford Street SE1 9NH London UK

Received: ((will be filled in by the editorial staff))

Supporting information for this article is available on the WWW under http://dx.doi.org/10.1002/adsc.201\#\#\#\#\#\#.((Please delete if not appropriate))

\begin{abstract}
Reductive amination can be carried in $i$ $\mathrm{PrOH} / \mathrm{H}_{2} \mathrm{O}$ as hydrogen sources using commercially available iron carbonyl complexes. Inside an aqueous alkaline environment, a hydridocarboferrate is formed and its reducing potential is exploited for hydrogenation of the imine (or iminium ion) in situ obtained from aldehydes or ketones, and primary or secondary amines in almost equimolar ratio. This completely sustainable and hydrogen-free process proceeds at $100{ }^{\circ} \mathrm{C}$ using $\mathrm{Fe}_{3}(\mathrm{CO})_{12}$ as catalyst precursor under convectional heating while $\mathrm{Fe}_{2}(\mathrm{CO})_{9}$ gave better results when the reaction was carried out under MW dielectric heating. Either enolizable and not-enolizable aldehydes may be successfully employed in reactions with aliphatic and aromatic amines.
\end{abstract}

Keywords: amines; iron catalysis; microwave; reduction; hydrides.

Amines represent a wide and important class of organic compounds, present in almost $40 \%$ of the registered active pharmaceutical principles (APIs) and in $20 \%$ of commercial agrochemicals. ${ }^{[1]}$ Several synthetic methodologies for their preparation have been described so far, among which reductive amination of carbonyl compounds is the first choice in fine chemical industries, especially when the preparation of secondary and tertiary amines is required. ${ }^{[2]}$ Reductive amination reactions are based on the formation of an imine (or an iminium ion) intermediate from a carbonyl substrate and a nucleophilic amine followed by a reductive step. The most common reducing agents employed in this step are: (i) metal hydrides as $\mathrm{NaBH}_{4}, \mathrm{LiAlH}_{4}$ or $\mathrm{NaBH}_{3}(\mathrm{OAc})$ used in stoichiometric amounts, ${ }^{[3]}$ (ii) molecular hydrogen (often at high pressure) in the presence of homogeneous or heterogeneous noble metal catalysts (i.e. $\mathrm{Pd}, \mathrm{Pt}, \mathrm{Rh}, \mathrm{Ir})^{[4]}$ or (iii) a hydride generated from a hydrogen transfer process catalyzed again by a noble metal. ${ }^{[5]}$ Although catalytic processes are more sustainable with respect to the non-catalytic ones, ${ }^{[6]}$ the use of noble metals as catalysts remain unappealing for industrial and pharmaceutical processes as shown by the limitations introduced by regulatory agencies that requires, for API registration, only small traces (ppm) of noble metals present in final product. ${ }^{[7]}$ Safer alternatives are represented by "green" metals such as $\mathrm{Cu}, \mathrm{Fe}$ or $\mathrm{Zn}$ catalyst. Recently, Fe catalysis emerged as an appealing field in organic chemistry due to the iron low toxicity, earth abundance and low cost. A number of different iron complexes have been developed to date for the formation of new C-C bond, ${ }^{[8]}$ for carbonylation ${ }^{[9]}$ and cycloadditions reactions, ${ }^{[10]}$ nucleophilic substitutions as well as other transformations recently reviewed. ${ }^{[1]}$ While iron complexes have been widely explored for the reduction of aldehydes, ketones and imine/iminium ions $^{[12-14]}$, Fe catalyzed reductive amination has been poorly investigated to date. ${ }^{[11 \mathrm{c}, 15-18]}$ The research groups of Piarulli, ${ }^{[16]}$ Renaud $^{[17]}$ and Beller ${ }^{[18]}$ recently reported different examples of Fe-catalyzed reductive amination (Scheme 1).

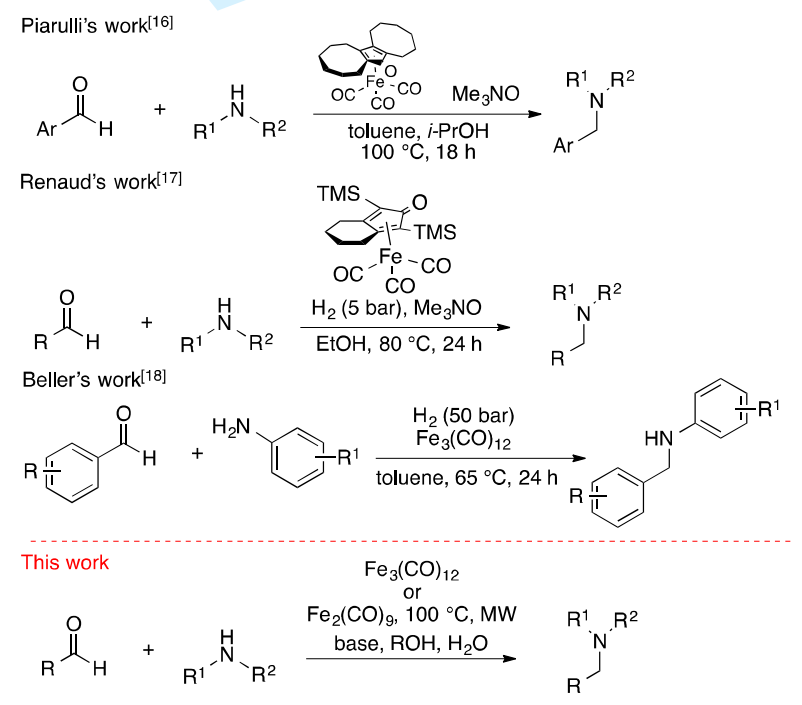

Scheme 1. State of the art. ${ }^{[16-18]}$ 
Tailor made Fe carbonyl complexes in the presence of $\mathrm{H}_{2}$ gas (Beller's method) ${ }^{[18]}$ and toluene (a notecofriendly solvent, Beller's and Piarulli's methods) are yet required. ${ }^{[16,18]}$ In addition, these approaches have been almost applied mainly to aromatic amines. ${ }^{[13,18]}$

Herein, we present an alternative iron catalyzed and hydrogen free method for the reductive amination of a wide variety of aromatic and aliphatic aldehydes and amines. Contrary to previously reported approaches where $\mathrm{Fe}$ is used to activate $\mathrm{H}_{2}$, we were intrigued by the possibility to employ a transient hydridocarboferrate, generated from iron carbonyl complexes in alkaline medium, as the hydrogen source in the reducing step of reductive amination reactions. The formation of carbonylhydridoferrates has been the subject of several studies mainly directed toward their stoichiometric applications in chemical reduction reactions. ${ }^{[19]}$ Only few reductive processes catalyzed by hydridocarboferrate have been described, some of them requiring $\mathrm{CO}$ atmosphere (from 1 to $100 \mathrm{~atm}$ ). ${ }^{[19 a]}$

Carbonylhydridoferrate can be easily generated starting rom $\mathrm{Fe}(\mathrm{CO})_{5}$ in alkaline medium as reported in equation $1 .{ }^{[19 \mathrm{a}, 20]}$

$\mathrm{Fe}(\mathrm{CO})_{5}+\mathrm{OH}^{-} \rightarrow\left[\mathrm{HFe}(\mathrm{CO})_{4}\right]^{-}+\mathrm{CO}$

Eq 1

Once $\left[\mathrm{HFe}(\mathrm{CO})_{4}\right]^{-}$has obtained, the reductive potential of the carbonylhydridoferrates might be exploited in an iron mediated reductive amination where water (the $\mathrm{OH}^{-}$source) is the hydrogen donor, a sustainable protocol with a potentially high impact on amine synthesis.

We first investigated the possibility to perform a reductive amination using $\mathrm{Fe}_{3}(\mathrm{CO})_{12}$ as precursor of the hydridodecarboferrate. Following our previous experience, the reaction of benzaldehyde with $p$ anisidine was chosen as the model to explore reaction conditions. 2-Propanol $(i-\mathrm{PrOH})$ was selected as the solvent as well as the potential hydride source, while an excess of the amine was employed to guarantee the alkaline medium. At first, the reaction was carried out under $\mathrm{CO}$ atmosphere in order to stabilize the expected catalytic species (Table 1, entry 1). The choice of $\mathrm{Fe}_{3}(\mathrm{CO})_{12}$ was based on our previous successful microwave-assisted aminocarbonylation of ynamides. ${ }^{\left[{ }^{[b]}\right]}$ In the first attempt, $p$-anisidine $\mathbf{2}$ was employed as both the reactant and the base, under microwave (MW) irradiation. $i$-PrOH was the solvent under $\mathrm{CO}$ atmosphere $(6.8 \mathrm{~atm})$ at $100{ }^{\circ} \mathrm{C}$ for 20 minutes and using 0.06 equivalents of $\mathrm{Fe}_{3}(\mathrm{CO})_{12}$. Only a $10 \%$ conversion of $\mathbf{2}$ into product $\mathbf{3}$ was observed. The presence of oxygen proved to be detrimental for the catalytic process; in fact, an improvement in the yields of $\mathbf{3}$ was observed when the reaction mixture was degassed before heating (Table 1, entry 2). A substantial increment from 35 to $80 \%$ conversion was observed when the reaction was carried out in a sealed tube charged with $1 \mathrm{~atm}$ of $\mathrm{CO}$, and heated for $12 \mathrm{~h}$ at $100^{\circ} \mathrm{C}$ into an oil bath (Table 1, entries 2-3).
Table 1. Optimization of reaction conditions.

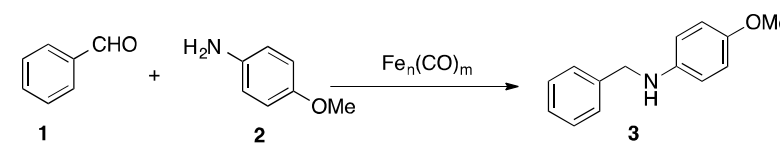

\begin{tabular}{|c|c|c|c|}
\hline En. & Cat. (eq.) & Reaction conditions & Conv $v^{b}$ \\
\hline $1^{\mathrm{a}}$ & $\begin{array}{l}\mathrm{Fe}_{3}(\mathrm{CO})_{12} \\
(0.06)\end{array}$ & $\begin{array}{l}\mathrm{CO}(6.8 \mathrm{~atm}), \mathrm{PrOH}, \mathrm{MW} \\
100^{\circ} \mathrm{C}, 20 \mathrm{~min}\end{array}$ & 10 \\
\hline $2^{\mathrm{a}, \mathrm{c}}$ & $\begin{array}{l}\mathrm{Fe}_{3}(\mathrm{CO})_{12} \\
(0.06)\end{array}$ & $\begin{array}{l}\mathrm{CO}(6.8 \mathrm{~atm}), i \mathrm{PrOH}, \mathrm{MW} \\
100^{\circ} \mathrm{C}, 20 \mathrm{~min}\end{array}$ & 35 \\
\hline $3^{\mathrm{a,c}}$ & $\begin{array}{l}\mathrm{Fe}_{3}(\mathrm{CO})_{12} \\
(0.06)\end{array}$ & $\mathrm{CO}(1 \mathrm{~atm}), i \operatorname{PrOH}, 100^{\circ} \mathrm{C}, 12 \mathrm{~h}$ & 80 \\
\hline $4^{\mathrm{a}, \mathrm{c}}$ & $\begin{array}{l}\mathrm{Fe}_{2}(\mathrm{CO})_{9} \\
(0.06)\end{array}$ & $\mathrm{CO}(1 \mathrm{~atm}), i \operatorname{PrOH}, 100^{\circ} \mathrm{C}, 12 \mathrm{~h}$ & 41 \\
\hline $5^{\mathrm{a}, \mathrm{c}}$ & $\begin{array}{l}\mathrm{Fe}_{2}(\mathrm{CO})_{9} \\
(0.06)\end{array}$ & $\begin{array}{l}\mathrm{CO}(1 \mathrm{~atm}), i \operatorname{PrOH}, \mathrm{MW} 100^{\circ} \mathrm{C}, \\
20 \mathrm{~min}\end{array}$ & 88 \\
\hline $6^{\mathrm{c}, \mathrm{d}}$ & $\begin{array}{l}\mathrm{Fe}_{3}(\mathrm{CO})_{12} \\
(0.2)\end{array}$ & $\begin{array}{l}\mathrm{PPh}_{3}(0.4 \mathrm{eq}), \mathrm{TEA}(0.4 \mathrm{eq}), \mathrm{CO} \\
(1 \mathrm{~atm}), i \mathrm{PrOH}, 12 \mathrm{~h}\end{array}$ & 32 \\
\hline $7^{\mathrm{c}, \mathrm{d}}$ & $\begin{array}{l}\mathrm{Fe}_{3}(\mathrm{CO})_{12} \\
(0.2)\end{array}$ & $\begin{array}{l}\text { DMP }(0.4 \text { eq), TEA }(0.4 \text { eq), CO } \\
(1 \mathrm{~atm}), i \operatorname{PrOH}, 12 \mathrm{~h}\end{array}$ & 76 \\
\hline $8^{\mathrm{c}, \mathrm{d}}$ & $\begin{array}{l}\mathrm{Fe}_{3}(\mathrm{CO})_{12} \\
(0.2)\end{array}$ & $\begin{array}{l}\text { DMAP }(0.4 \text { eq }), C O(1 \mathrm{~atm}) \\
i \operatorname{PrOH}, 100^{\circ} \mathrm{C}, 12 \mathrm{~h}\end{array}$ & 78 \\
\hline $9^{\mathrm{c}, \mathrm{d}}$ & $\begin{array}{l}\mathrm{Fe}_{3}(\mathrm{CO})_{12} \\
(0.2)\end{array}$ & $\begin{array}{l}\mathrm{DMAP}(0.2 \text { eq), } \mathrm{CO}(1 \mathrm{~atm}), \\
i \mathrm{PrOH}, 12 \mathrm{~h}\end{array}$ & 60 \\
\hline $10^{\mathrm{c}, \mathrm{d}}$ & $\begin{array}{l}\mathrm{Fe}_{3}(\mathrm{CO})_{12} \\
(0.2)\end{array}$ & DMAP (0.4 eq), $i \mathrm{PrOH}, 12 \mathrm{~h}$ & 89 \\
\hline $11^{\mathrm{c}, \mathrm{d}}$ & $\begin{array}{l}\mathrm{Fe}_{3}(\mathrm{CO})_{12} \\
(0.06)\end{array}$ & DMAP $(0.4$ eq), $i \operatorname{PrOH}, 12 \mathrm{~h}$ & 80 \\
\hline $12^{\mathrm{c}, \mathrm{d}}$ & $\begin{array}{l}\mathrm{Fe}_{3}(\mathrm{CO})_{12} \\
(0.04)\end{array}$ & DMAP $(0.4$ eq), $i \operatorname{PrOH}, 12 \mathrm{~h}$ & 52 \\
\hline $13^{\mathrm{c}, \mathrm{e}}$ & $\begin{array}{l}\mathrm{Fe}_{3}(\mathrm{CO})_{12} \\
(0.04)\end{array}$ & $\mathrm{NaOH}(1 \mathrm{eq}), i \mathrm{PrOH}, 12 \mathrm{~h}$ & 49 \\
\hline $14^{\mathrm{c}, \mathrm{e}}$ & $\begin{array}{l}\mathrm{Fe}_{3}(\mathrm{CO})_{12} \\
(0.06)\end{array}$ & $\mathrm{NaOH}(0.4 \mathrm{eq}), i \mathrm{PrOH}, 12 \mathrm{~h}$ & 45 \\
\hline $15^{\mathrm{c}, \mathrm{e}}$ & $\begin{array}{l}\mathrm{Fe}_{3}(\mathrm{CO})_{12} \\
(0.04)\end{array}$ & $\begin{array}{l}\mathrm{NaOH}(0.4 \mathrm{eq}), \mathrm{DMAP}(0.4 \mathrm{eq}), \\
i \mathrm{PrOH}, 12 \mathrm{~h}\end{array}$ & 85 \\
\hline $16^{\mathrm{c}, \mathrm{e}}$ & $\begin{array}{l}\mathrm{Fe}_{3}(\mathrm{CO})_{12} \\
(0.04)\end{array}$ & $\begin{array}{l}\mathrm{NaOH}(0.4 \text { eq), DMAP }(0.4 \text { eq), } \\
i \operatorname{PrOH} / \mathrm{H}_{2} \mathrm{O}(10: 1), 12 \mathrm{~h}\end{array}$ & 95 \\
\hline $17^{\mathrm{c}, \mathrm{e}}$ & $\begin{array}{l}\mathrm{Fe}_{2}(\mathrm{CO})_{9} \\
(0.06)\end{array}$ & $\begin{array}{l}\mathrm{NaOH}(0.5 \text { eq), DMAP }(0.2 \mathrm{eq}) \\
i \mathrm{PrOH} / \mathrm{H}_{2} \mathrm{O}(10: 1), \mathrm{MW}, 15 \mathrm{~min}\end{array}$ & 98 \\
\hline
\end{tabular}

[a] 1 (1 eq), 2 (2 eq), Fe complex 0.06 eq; [b] Conversion determined by GC/MS analysis; [c] The reaction mixture was degassed before irradiation. [d] 1 (1 eq), 2 (1 eq), $100{ }^{\circ} \mathrm{C}$. [e] $\mathbf{1}(1.5 \mathrm{eq}), 2(1 \mathrm{eq}), 100^{\circ} \mathrm{C}$.

Interestingly, when $\mathrm{Fe}_{2}(\mathrm{CO})_{9}$ was used as Fe source, an opposite behavior was observed.Convectional heating (oil bath) led to 3 with $45 \%$ conversion while $88 \%$ conversion was obtained when $\mathbf{2}$ was reacted for $1 \mathrm{~h}$ at $100{ }^{\circ} \mathrm{C}$ under MW dielectric heating (Table 1, entries 4-5).

Starting from these data, we further investigated the reductive amination protocol in the presence of $\mathrm{Fe}_{3}(\mathrm{CO})_{12}$ or $\mathrm{Fe}_{2}(\mathrm{CO})_{9}$ both under convectional heating and $\mathrm{MW}$ dielectric heating respectively (Table 1, entries 6-17). Different solvents, additives and bases were employed and, in order to make the protocol sustainable and atom economic, the starting aldehyde $\mathbf{1}$ and the amine $\mathbf{2}$ were used in equimolar ratio (for additional experiments see Table S1). When 
a 1:1 mixture of $\mathrm{PPh}_{3}$ and TEA in the presence of $\mathrm{Fe}_{3}(\mathrm{CO})_{12}(0.2 \mathrm{eq})$ and $\mathrm{CO}(1 \mathrm{~atm})$ was used, the amine 3 was obtained with $32 \%$ conversion in $i$ $\mathrm{PrOH}$ (Table 1, entry 6). The use of DMAP instead of $\mathrm{PPh}_{3}$ led to 3 with $76 \%$ conversion in $i \mathrm{PrOH}$ (Table 1 , entry 7). Additional improvements in the conversion were observed when DMAP was used without TEA as reported in entry 8. Lowering down the amount of DMAP to less than $0.4 \mathrm{eq}$, gave the formation of $60 \%$ of amine 3 together with a $25 \%$ of unreacted imine 5 (Table 1, entry 9). Finally, based to the observation that an increase in the $\mathrm{CO}$ pressure did not have any effect on the conversion, a CO-free reaction was investigated. Interestingly, under these conditions, the amine $\mathbf{3}$ was still formed with $89 \%$ conversion (Table 1 , entry 10). Thus, additional efforts were undertaken to further optimize the CO-free reaction (Table 1, entries 11-17). With DMAP alone, the amount of $\mathrm{Fe}_{3}(\mathrm{CO})_{12}$ could not be lowered to less than $6 \mathrm{~mol} \%$ without a dramatic drop in the conversion (Table 1, entries 11-12). Analogously, replacement of DMAP with $\mathrm{NaOH}$ decreased the conversion, even using the higher amount of the iron carbonyl complex (Table 1, entries 13-14). However, with a correct blend of aqueous $\mathrm{NaOH}$ and DMAP, a final high conversion of $\mathbf{1}$ and $\mathbf{2}$ into amine $\mathbf{3}$ was observed with both the iron carbonyl complexes (Table 1, entries 15-17). However, a strong link between the iron catalyst used and the heating source exists. In fact, whilst $\mathrm{Fe}_{3}(\mathrm{CO})_{12}$ worked well under convectional heating (oil bath, $100{ }^{\circ} \mathrm{C} 12 \mathrm{~h}$ ), the safer unvolatile ${ }^{[2 \mathrm{C}]}$ $\mathrm{Fe}_{2}(\mathrm{CO})_{9}$ gave excellent conversion only under MW dielectric heating at $100{ }^{\circ} \mathrm{C}$ for $10 \mathrm{~min}$. This different behavior may be related to the different stability interaction with MWs: $\mathrm{Fe}_{3}(\mathrm{CO})_{12}$ generates local hot spots during MW heating contrary to $\mathrm{Fe}_{2}(\mathrm{CO})_{9}$. The behavior of the two complexes in microwave rotational spectroscopy is also very different, ${ }^{[22]}$ suggesting a diverse heating profile during MW irradiation. Looking to the electrons exchanged during the red-ox process, the reductive amination requires $2 \mathrm{e}^{-}$for each imine molecule. As $\mathrm{Fe}_{3}(\mathrm{CO})_{12}$ may potentially transfer a maximum of $30 \mathrm{e}^{\mathrm{e}}, 1$ mole of the metal complex may process a maximum of 15 moles of imine. Thus, a catalytic process should require less than $6.7 \mathrm{~mol} \%$ of $\mathrm{Fe}_{3}(\mathrm{CO})_{12}$ or, $9.1 \mathrm{~mol} \%$ of $\mathrm{Fe}_{2}(\mathrm{CO})_{9}$. Although a complete electron exchange is not plausible, the minimum amount required for high conversion was $4 \mathrm{~mol} \%$ of $\mathrm{Fe}_{3}(\mathrm{CO})_{12}$ and 6 mol\% of $\mathrm{Fe}_{2}(\mathrm{CO})_{9}$ proving that the reaction is not a stoichiometric iron complex reduction. Optimized conditions for $98 \%$ conversion of $\mathbf{1}$ and $\mathbf{2}$ (equimolar) into amine 3 were $6 \mathrm{~mol} \%$ of $\mathrm{Fe}_{2}(\mathrm{CO})_{9}, 0.4$ eq of DMAP in $i$-PrOH/water, alkalinized with 0.4 eq of $\mathrm{NaOH}$, as solvent and hydride source, at $100{ }^{\circ} \mathrm{C}$ for 15 min under MW dielectric heating. Following these conditions, compound $\mathbf{3}$ was obtained in comparable yields with respect to Beller's ${ }^{18}$ (97\% yield) and Piarulli's ${ }^{16}$ (99\% yield) methods. The scope of the reaction was finally explored, and the results are summarized in Table 2.
Table 2. Reaction scope.

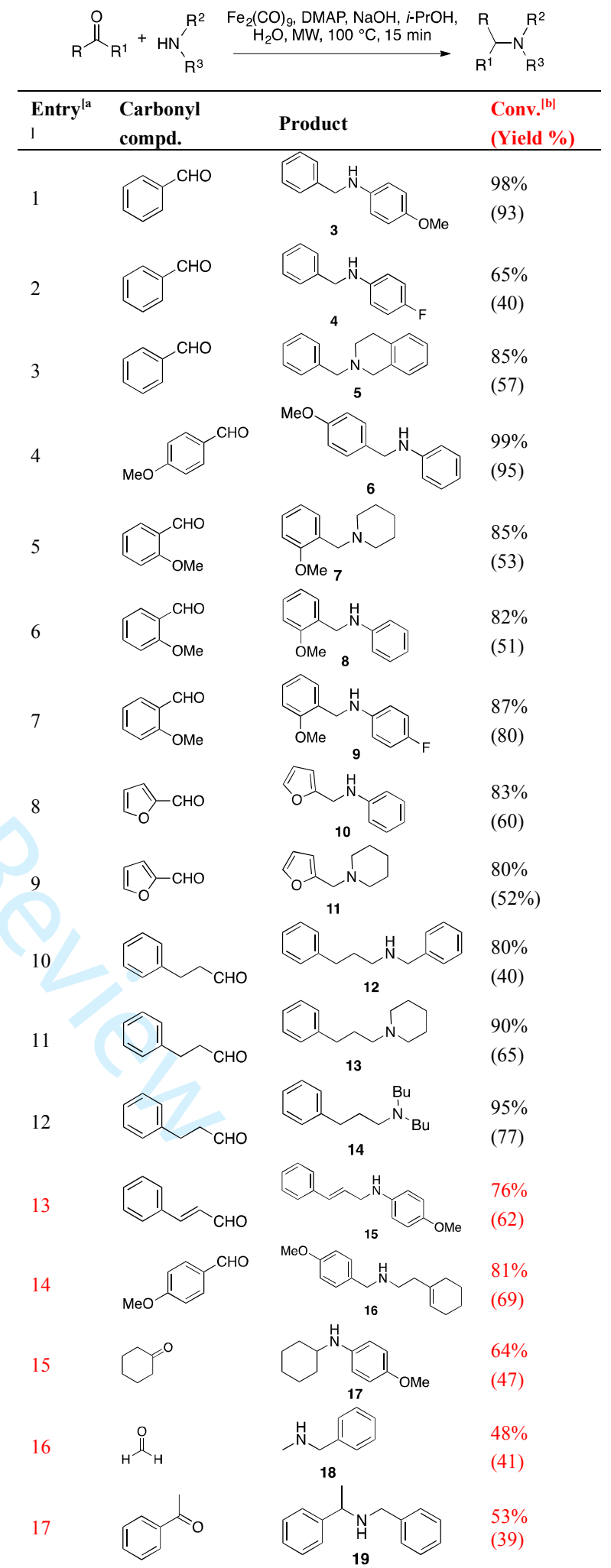

[a] Carbonyl compound (1.5 eq), amine (1 eq), $\mathrm{Fe}_{2}(\mathrm{CO})_{9}$ (0.06 eq), $\mathrm{NaOH}(0.5$ eq), DMAP ( $0.2 \mathrm{eq}), i-\mathrm{PrOH} / \mathrm{H}_{2} \mathrm{O}$ (10:1), MW, $100{ }^{\circ} \mathrm{C}, 15 \mathrm{~min}$. [b] Conversion was determined by GC/MS analysis while yields are referred to isolated and fully characterized compounds. 
Not-enolizable aldehydes (precursors of products 311) gave acceptable to good yields of the corresponding secondary and tertiary amines (Table $2)$. The only exception was represented by the less nucleophilic $p$-fluoro aniline, although compound 4 was isolated in $40 \%$ yield (Table 2 , entry 2). Enolizable aldehydes could be also used in this reaction leading to products 12-14 with good conversions (Table 2, entries 10-12). Particularly, compound 13 was obtained in comparable yields with respect to Renaud's ${ }^{17}$ protocol. The reaction conditions are compatible with the presence of a double bond (Table 2, entry 13) and an aqueous solution of formaldehyde can be used for methylation of a primary amine (Table 2, entry16). Ketones react also although with low conversion/yield (Table 2, entries 15 and 17). As expected, the reaction follows the general trend of reductive amination that occurs with better yields when non-enolizable carbonyl compounds and electronrich aromatic amines were employed. All the reaction in Table 2 were performed using $\mathrm{Fe}_{2}(\mathrm{CO})_{9}$ under $\mathrm{MW}$ dielectric heating. Reaction yields using $\mathrm{Fe}_{3}(\mathrm{CO})_{12}(0.04 \mathrm{eq})$ under convectional heating are reported in SI.

Before the proposal of a convincing mechanism, the possibility of a radical process was excluded as the reaction worked well in the presence of radical scavenger BHT. Then, a study on deuterium incorporation was carried out with $\mathrm{D}_{2} \mathrm{O}$ and $i-\mathrm{PrODd}_{8}$ (SI). Maximum deuterium incorporation $(93 \%)$ was observed when both deuterated reagents were employed, while with $\mathrm{H}_{2} \mathrm{O}$ and $i$ - $\mathrm{PrODd}_{8}$ a $20 \%$ of the deuterated amine was obtained. Although $\mathrm{D}_{2} \mathrm{O}$ (or $\mathrm{OD}^{-}$) seems to be the major hydride source, $i-\mathrm{PrOH}$ was oxidized to acetone, identified in the final reaction mixture. On the other hand, DMAP seems to be also required for a high yield reductive amination.

Based on these observations, the proposed mechanism is described in Scheme 2. In a first step, the $\mathrm{Fe}$ carbonyl and $\mathrm{NaOH}$ react generating the carbonylhydridoferrate intermediate $\mathbf{A}$ with contemporary elimination of a molecule of $\mathrm{CO}_{2}$ (Step i. in Scheme 1). The active catalyst $\mathbf{A}$ transfers the hydride ion to the in situ formed imine $\mathbf{B}$ that is immediately protonated by $\mathrm{H}_{2} \mathrm{O}$ producing the expected amine $\mathbf{C}$ and $\mathrm{NaOH}$ (Step ii.). Contemporary, DMAP yields the complex D which reacts with $\mathrm{NaOH}$, regenerating $\mathbf{A}$ and DMAP $N$ oxide (Step iii.). DMAP is finally recycled through a (Fe catalyzed) reduction mediated by $i-\mathrm{PrOH}$, thus producing acetone and $\mathrm{H}_{2} \mathrm{O}$ (Steps iv. and v.). This mechanism is coherent with the results of deuterium incorporating experiments and with a final red-ox balance recruiting $i$-PrOH as reducing agent (the scheme relative to the mechanism with deuterated reagents is reported in $\mathrm{SI}$ ).

In conclusion, a sustainable iron catalyzed and hydrogen free protocol for the reductive amination of amines and aldehydes has been developed. This procedure is more sustainable than standard metal catalyzed reductive amination reaction as it counts on the catalysis of the biocompatible safe iron carbonyl complex with $i-\mathrm{PrOH} / \mathrm{H}_{2} \mathrm{O}$.

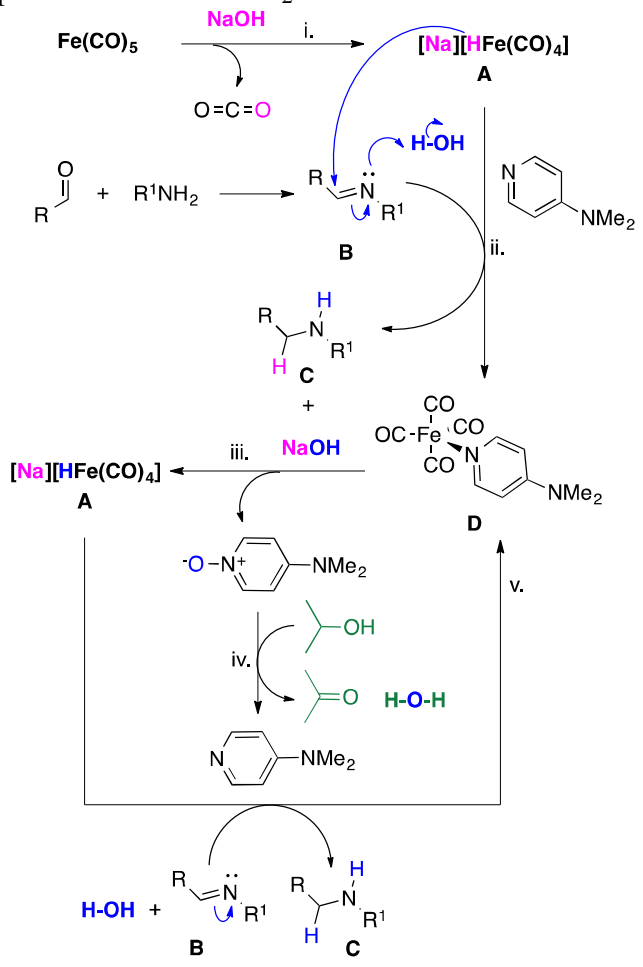

Scheme 2. Proposed reaction mechanism (exemplified with $\mathrm{Fe}(\mathrm{CO})_{5}$ )

The scope of the reaction is wide, and the protocol may be applied to both aliphatic and aromatic amines as well as to enolizable and not-enolizable aldehydes. Finally, the reaction can be carried out in short reaction times and the products can be isolated after simple filtration on a silica pad.

\section{Experimental Section}

General procedure to obtain $\mathrm{N}$-(4methoxyphenyl)benzylamine (3): $M W$ dielectric heating. in a $\mathrm{MW}$ tube, under $\mathrm{N}_{2}$ atmosphere and under stirring, $\mathrm{Fe}_{2}(\mathrm{CO})_{9}(29 \mathrm{mg}, 0.08 \mathrm{mmol})$ is solubilized in a mixture of $i$-PrOH $(2.5 \mathrm{ml})$ and water $(0.25 \mathrm{ml})$. The mixture is degassed by sonication bubbling $\mathrm{N}_{2}$ for $3 \mathrm{~min}$. $\mathrm{NaOH}$ (40 $\mathrm{mg}, 1 \mathrm{mmol}$ ) is added and the mixture left under stirring for 5 minutes. benzaldehyde $(212 \mathrm{mg}, 2 \mathrm{mmol}), p$-anisidine (246 mg, $2 \mathrm{mmol}$ ) and DMAP (49 $\mathrm{mg}, 0.4 \mathrm{mmol}$ ) are added to the reaction mixture. The tube is then inserted in a MW cavity and heated for 15 minutes at $100^{\circ} \mathrm{C}$, using a maximum power of $150 \mathrm{~W}$ (max internal pressure set at 250 psi). After cooling, the mixture is diluted with $\mathrm{CH}_{2} \mathrm{Cl}_{2}$, dried over dry $\mathrm{Na}_{2} \mathrm{SO}_{4}$, filtered and the solvent removed under vacuum. The residue is dissolved into dimethoxyethane $(5 \mathrm{~mL})$ and passed through a short path of silica. Evaporation of the solvent gave product 3 (429 mg, $93 \%$ yield), m.p. $48-50{ }^{\circ} \mathrm{C}$, lit ${ }^{[23]}$ m.p. $49-50{ }^{\circ} \mathrm{C}$.

Convectional heating: in a sealed tube, under $\mathrm{N}_{2}$ atmosphere and under stirring, $\mathrm{Fe}_{3}(\mathrm{CO})_{12}(60 \mathrm{mg}, 0.12$ $\mathrm{mmol})$ is solubilized in a mixture of $i-\mathrm{PrOH}(2.5 \mathrm{ml})$ and water $(0.25 \mathrm{ml})$. The mixture is degassed by sonication bubbling $\mathrm{N}_{2}$ for $3 \mathrm{~min}$. $\mathrm{NaOH}$ (40 mg, $1 \mathrm{mmol}$ ) is added and the mixture left under stirring for 5 minutes. benzaldehyde $(212 \mathrm{mg}, 3 \mathrm{mmol}), p$-anisidine $(246 \mathrm{mg}, 2$ $\mathrm{mmol}$ ) and DMAP (49 $\mathrm{mg}, 0.4 \mathrm{mmol}$ ) are added to the 
reaction mixture. The reaction mixture is heated under stirring for $12 \mathrm{~h}$ at $130{ }^{\circ} \mathrm{C}$ (external bath temperature, internal temperature previously determined for these conditions $100^{\circ} \mathrm{C}$ ). After cooling, the mixture is diluted with $\mathrm{CH}_{2} \mathrm{Cl}_{2}$, dried over dry $\mathrm{Na}_{2} \mathrm{SO}_{4}$, filtered and the solvent removed under vacuum. The residue is dissolved into dimethoxyethane $(5 \mathrm{~mL})$ and passed through a short path of silica. Evaporation of the solvent gave product 3 (387 $\mathrm{mg}, 91 \%$ yield), m.p. $48-50^{\circ} \mathrm{C}$.

\section{Acknowledgements}

Dipahrma Francis srl (Milan, I) is gratefully acknowledged for financial support. EP thanks italian Ministero dell'Istruzione, dell'Università e della Ricerca (MIUR) for financial support (PRIN2015LZE994). MIUR is also acknowledged for financial support through the program "Dipartimenti di Eccellenza - 2018$2022 ”$

\section{References}

[1] Pharmaceuticals: Classes, Therapeutic agents, Areas of Application J.L. McGuire ed, Wiley - VCH, Weinheim, 2001, Vol. 1-4.

[2] For recent reviews, see: a) A.F. Abel-Magid, S.J. Mehrman, Org. Proc. Res. Devel., 2006, 10, 971-1031; b) T. C. Nugent, M. El-Shazly, Adv. Synth. Catal., 2010, 352, 753-819; c) H. Alinezhad, H. Yavari, F. Salehian, Curr. Org. Chem., 2015, 19, 1021-1049.

[3] E. W. Baxter, A. B. Reitz, E. W. Baxter, A. B. Reitz, in Org. React., John Wiley \& Sons, Inc., Hoboken, NJ, USA, 2002, pp. 1-714.

[4] a) J. L. Klinkenberg, J. F. Hartwig, Angew. Chem. Int. Ed., 2011, 50, 86-95; b) X.-L. Du, G. Tang, H.-L. Bao, Z. Jiang, X.-H. Zhong, D.S. Su, J.-Q. Wang, ChemSusChem, 2015, 8, 3489-3496; c) J. GallardoDonaire, M. Ernst, O. Trapp, T. Schaub, Adv. Synth. Catal., 2016, 358, 358-363.

[5] a) J. Zhou, B. List, J. Am. Chem. Soc., 2007, 129, 7498-7499; b) T. Liu, X. Wang, D. Yin, RSC Advances, 2015, 5, 75794-75805; c) V. R. Jumde, E. Petricci, C. Petrucci, N. Santillo, M. Taddei, L. Vaccaro, Org. Lett., 2015, 17, 3990-3993; d) J. W. Park, Y. K. Chung, ACS Catal., 2015, 5, 4846-4850; e) M. Zhu, Tetrahedron Lett., 2016, 57, 509-511.

[6] I. Delidovich, R. Palkovits, Green Chem. 2016, 18, 590-593.

[7] a) B. Plietker, Synlett 2010, 2049-2058. b) See also EMA document WC500003587: http://www.emea.europa.eu/docs/en GB/document lib rary/Scientific guideline/2009/09/WC500003587.pdf

[8] a) J. Legros, B. Figadere, Nat. Prod. Rep., 2015, 32, 1541-1555; b.) A. Casitas, H. Krause, R. Goddard, A. Fürstner, Angew. Chem. Int. Ed., 2015, 54, 1521-1526; c) Z. Rappoport, in Chemistry of Organoiron Compounds, I Marek, ed., 2014, pp 499-538.

[9] a) K. M. Driller, H. Klein, R. Jackstell, M. Beller, Angew. Chem. Int. Ed., 2009, 48, 6041-6044; b.) M. Pizzetti, A. Russo, E. Petricci, Chem. Eur. J., 2011, 17, 4523-4528; c) M. D. Greenhalgh, A. S. Jones, S. P. Thomas, P. Stephen, ChemCatChem, 2015, 7, 190-222. [10] a) D. Toulemon, B. Pichon, C. Leuvrey, S. Zafeiratos, V. Papaefthimiou, X. Cattoen, S. Begin-Colin, Chem.
Mater., 2013, 25, 2849-2854; b) S. J. Perez, M. Purino, P. O. Miranda, V. S. Martin, I. Fernandez, J. I. Padron, Chem. Eur. J., 2015, 21, 15211-15217; c) J. M. Hoyt, V. A. Schmidt, A. M. Tondreau, P. J. Chirik, Science, 2015, 349, 960-963; d) M.-N. Zhao, L. Yu, R.-R. Hui, Z.-H. Ren, Y.-Y. Wang, Z.-H. Guan, ACS Catal. 2016, 6, 3473-3477.

[11] a) B. Plietker, Iron catalysis in organic chemistry: reactions and applications, Wiley-VCH, Weinheim, 2008; b) C. Bolm, J. Legros, J. Le Paih, L. Zani, Chem. Rev. 2004, 104, 6217-6254; c) C. P. Casey, J. B. Johnson J. Am. Chem. Soc., 2005, 127, 1883-1894; d) C. P. Casey, H. Guan J. Am. Chem. Soc., 2007, 129, 5816-5817; e) C. P. Casey, H. Guan J. Am. Chem. Soc., 2009, 131, 2499-2507; f) A. Fürstner, Angew. Chem. Int. Ed., 2009, 48, 1364-1367; g) K. Junge, K. Schröder, M. Beller, Chem. Comm., 2011, 47, 48494859; h) L. Huang, M. Arndt, K. Gooßen, H. Heydt, L. J. Gooßen, Chem. Rev., 2015, 115, 2596-2697; i) I. Bauer, H.-J. Knölker, Chem. Rev., 2015, 115, 31703387.

[12] a) P. E. Sues, K. Z. Demmans, R. H. Morris Dalton Trans., 2014, 43, 7650-7667; b) C. Sui-Seng, F. Freutel, A. J. Lough, R. H. Morris Angew. Chem., Int. Ed., 2008, 47, 940-943; c) C. Sui-Seng, F. N. Haque, A. Hadzovic, A.-M. Putz, V. Reuss, N. Meyer, A. J. Lough, M. Zimmer-De Iuliis, R. H. Morris, Inorg. Chem., 2009, 48, 735-743; d) N. Meyer, A. J. Lough, R. H. Morris, Chem. Eur. J., 2009, 15, 5605-5610.

[13] a) S. Fleischer, S. Zhou, K. Junge, M. Beller Angew. Chem. Int. Ed., 2013, 52, 5120-5124; b) G.Wienhöfer, F. A. Westerhaus, K. Junge, M. Beller, J. Organomet. Chem. 2013, 744, 156-159S; c) S. Elangovan, J.-B. Sortais, M. Beller, C. Darcel, Angew. Chem. Int. Ed., 2015, 54, 14483-14486.

[14] a) S. Zhou, S. Fleischer, K. Junge, M. Beller, Angew. Chem. Int. Ed. 2011, 50, 5120-5124; b) D. S. Mérel, M. Elie, J.-F. Lohier, S. Gaillard, J.-L. Renaud, Chem CatChem 2013, 5, 2939-2945; c) P. O. Lagaditis, P. E. Sues, J. F. Sonnenberg, K. Y. Wan, A. J. Lough, R. H. Morris, J. Am. Chem. Soc. 2014, 136, 13671380; d) T. Stemmler, A.-E. Surkus, M.-M. Pohl, K. Junge, M. Beller, ChemSusChem 2014, 7, 3012-3016; e) D. Brenna, S. Rossi, F. Cozzi, M. Benaglia, Org. Biomol. Chem. 2017, 15, 5685-5688;

[15] a) B.-L. Yang, S.-K. Tian, Eur. J. Org. Chem., 2007, 4646-4650; b) S. Enthaler, ChemCatChem, 2010, 2, 1411-141; c) S. Zhou, S. Fleischer, H. Jiao, K. Junge, M. Beller, Adv. Synth. Catal. 2014, 356, 3451-3455; d) S. Moulin, H. Dentel, A. Pagnoux-Ozherelyeva, S. Gaillard, A. Poater, L. Cavallo, J.-F. Lohier, J.-L. Renaud, Chem. Eur. J. 2013, 19, 17881-17890; e) O. I. Afanasyev, D. Usanov, D. Chusov, Org. Biomol. Chem. 2017, 10164-10166.

[16] S. V. Facchini, M. Cettolin, X. Bai, G. Casamassima, L. Pignataro, C. Gennari, U. Piarulli Adv. Synth. Catal. 2018, 360, 1054-1059.

[17] a) A. Pagnoux-Ozherelyeva, N. Pannetier, M. D. Mbaye, S. Gaillard, J.-L. Renaud, Angew. Chem. Int. Ed., 2012, 51, 4976-4980; b) T.-T. Thai, D. S. Mérel, A. Poater, S. Gaillard, J.-L. Renaud, Chem. Eur. J. 2015, 21, 7066-7070. 
[18] S.Fleischer, S. Zhou, K. Junge, M. Beller Chem. Asian J., 2011, 6, 2240-2245.

[19] a) J.J. Brunet, Chem. Rev., 1990, 90, 1041-1059 and references therein; b) M. Periasamy, C. Rameshkumar, U. Radhakrishnan, A. Devasagayaraj, Curr. Science, 2000, 78, 1307-1313.

[20] J. Pospíšil, Synlett 2005, 2543-2544 and references therein.
[21] C. Elschenbroich, Organometallics: A Concise Introduction, $\mathrm{VCH}, 1992$.

[22] a) L. R. Thorne, W. D. Gwinn, J. Am. Chem. Soc. 1982, 104, 3822-3827. b) O. Indris, W. Stahl, Phys. Chem. Chem. Phys. 2000, 2, 319-322

[23] X. Zhu, L. Su, L. Huang, G. Chen, J. Wang, H. Song, Y. Wan, Eur. J. Org. Chem. 2008, 635-642. 


\section{UPDATE}

An Iron Catalyzed Reductive Amination of

Aldehydes in Isopropyl Alcohol/Water media as

Hydrogen Sources

Adv. Synth. Catal. Year, Volume, Page - Page

Elena Petricci,* Niccolò Santillo, Daniele Castagnolo, Elena Cini and Maurizio Taddei* 